


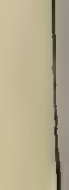


NBSIR 76-1079 (R)

\section{Tensile Tests of Pultruded Round Rods}

Nixon Halsey and Leonard Mordfin

Engineering Mechanics Section

Mechanics Division

Institute for Basic Standards

National Bureau of Standards

Washington, D. C. 20234

April 1976

Final

Prepared for

American Society for Testing and Materials

Section D20.18.02 on Reinforced Plastics Pultruded Shapes 


\section{TENSILE TESTS OF PULTRUDED ROUND RODS}

Nixon Halsey and Leonard Mordfin

Engineering Mechanics Section

Mechanics Division

Institute for Basic Standards

National Bureau of Standards

Washington, D. C. 20234

April 1976

Final

Prepared for

American Society for Testing and Materials

Section D20.18.02 on Reinforced Plastics Pultruded Shapes

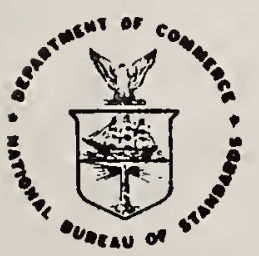

U.S. DEPARTMENT OF COMMERCE, Elliot L. Richardson, Socrotary

Dr. Botoy Anchet-dohnean, Asctitant Scaroteny for Scionco and Technology

NATIONAL BUREAU OF STANDARDS. Emoat Ambler. Acting Director 

1. INTRODUCTION

2. SPECIMENS

3. TEST METHOD

3.1 End Fittings

2

3.2 Testing Procedure

4. TEST RESULTS

5. DISCUSSION 

TENSILE TESTS OF PULTRUDED ROUND RODS

Nixon Halsey and Leonard Mordfin

\section{ABSTRACT}

The Engineering Mechanics Section of the National Bureau of Standards (NBS) conducted sixty-seven tensile tests on pultruded round rods as part of an ASTM interlaboratory testing program which was established to assess and to compare various test methods which are currently used by different testing organizations. The test methods used by NBS are described and the test results are given.

Key Words: Interlaboratory tests; plastics, glass fiberreinforced; pultrusions; reinforced plastics; round-robin tests; tensile strength; tensile tests; test methods, tensile; standards, voluntary.

\section{INTRODUCTION}

As a necessary step toward the promulgation of voluntary product specifications for pultrusions, ASTM Section D20.18.02 on Reinforced Plastics Pultruded Shapes has been pursuing the development of a standard tensile test method for round rod. A preliminary survey has revealed that there are almost as many different methods in use as there are laboratories which conduct such tests. Therefore, in order to provide data which could be used to evaluate and compare these different methods, an interlaboratory testing program was established.

The principal part of the program involved the voluntary participation of seven pultrusion manufacturers and nine testing organizations. With few exceptions, each pultruder submitted samples of glass fiberreinforced-polyester rod in two preselected diameters, and each testing organization conducted tensile tests on specimens of both diameters from each manufacturer. Each testing organization was required to conduct the tests using its own preferred method, to describe the method, and to furnish the results of its tensile strength measurements.

By virtue of its unbiased position as neither a manufacturer nor a large user of pultrusions, and its experience in test methods of this kind, the Engineering Mechanics Section of NBS was invited to coordinate the collection and distribution of the sample materials in order to maintain the anonymity of the pultruders, and also to participate in the program as one of the testing organizations.

This report presents a description of the methods used and the test results obtained by the Engineering Mechanics Section. 


\section{SPECIMENS}

Specimens were furnished in two nominal diameters, $1 / 2$ in and $1 / 8$ in $(13 \mathrm{~mm}$ and $3 \mathrm{~mm})$, each 36 in $(0.91 \mathrm{~m})$ long. Each specimen was color coded on one end, a single color being used to designate all of the specimens from each pultruder.

\section{TEST METHOD}

\subsection{End Fittings}

The NBS H3M experimental end fitting, Figure 1, was used for all of the 1/2-in (13-mm) diameter specimens. In order to mount this fitting on a rod, the inside surface of the fitting was first coated with an epoxy-release agent. The rod was then passed through the fitting and a cruciform wedge, Figure 2, was driven into the end of the rod, concentrically, dividing the end into four quarters and wedging the quarters apart. The periphery of the rod, where it emerged from the fitting, was then built up with tape to provide a seal. The cavity in the fitting was then filled with the potting compound, which was subsequently cured for approximately two hours at $163^{\circ} \mathrm{F}\left(74^{\circ} \mathrm{C}\right.$ ) using infrared lamps.

The potting compound used for all of the specimens consisted of two parts of epoxy resin adhesive $\mathrm{C}-4$ and three parts of activator $\mathrm{W}$, both available from Armstrong Products Company, Warsaw, Indiana.*

In contrast to the situation with $1 / 2-i n$ (13-mm) diameter rods, the Engineering Mechanics Section has relatively little experience in the testing of $1 / 8-$ in $(3-\mathrm{mm})$ diameter rods. H3M end fittings were not available for rods of this size. Several potting heads for synthetic rope (No. 9901, Reliable Electric Company, Franklin Park, Illinois) were on hand, however, and these were used as much as possible. The procedure for mounting these on the rod specimens was essentially the same as that described above for the H3M end fittings, except that cruciform wedges were not used. Instead, the end of the rod was quartered with a saw and the quarters were wedged apart by threading a wood screw into the rod end.

*Certain commercial equipment and materials are identified in this report in order to adequately specify the experimental procedure. In no case does such identification imply recommendation or endorsement by the National Bureau of Standards, nor does it imply that the material or equipment is necessarily the best available for the purpose. 
Unfortunately, the quantity of these potting heads which was available for this work was inadequate, and a simple shear-type end fitting was devised for use in most of the tests on 1/8-in (3-mm) diameter rod. This consisted of a 12-in (300-mm) length of steel pipe having an inside diameter of $5 / 8 \mathrm{in}(16 \mathrm{~mm})$ and a wall thickness of $0.10 \mathrm{in}(2.5 \mathrm{~mm})$. The end of the pipe was sealed with a plastic plug, the rod was inserted concentrically, and the cavity was filled with the potting compound which was then cured.

\subsection{Testing Procedure}

The 1/2-in (13-mm) diameter specimens were tested in a $400000-1 \mathrm{bf}$ (1.8-MN) capacity screw-powered testing machine using the $800001 \mathrm{bf}$ (360-kN) loading range. The H3M end fittings were gripped in the machine's wedge-type jaws and the specimens were loaded to failure, in tension, at a controlled crosshead speed of $0.2 \mathrm{in} / \mathrm{min}(0.08 \mathrm{~mm} / \mathrm{s})$.

The jaws in this machine could not properly accommodate the end fittings on the 1/8-in (3-mm) diameter specimens, so these specimens were tested in a $60000-1 \mathrm{bf}(270-\mathrm{kN})$ capacity hydraulic-powered testing machine using the 2400-lbf (11-kN) loading range. The pipe fittings were gripped in the machine's wedge-type jaws while the Reliable fittings were gripped through a thimble-and-eye attachment which provided a reasonably good measure of self-alinement. This testing machine is not equipped for controlled crosshead speeds so these specimens were loaded to failure at a constant loading rate of $15001 \mathrm{bf} / \mathrm{min}(110 \mathrm{~N} / \mathrm{s})$.

\section{TEST RESULTS}

For each test the maximum load was recorded, and the apparent manner in which failure initiated was observed. The test results are given in Table 1, in which the failure modes are classified into three categories: (a) failures which appeared to have initiated in, or adjacent to, an end fitting; (b) failures which appeared to have initiated in the free lengths of the specimens, i.e., at a location apart from the fittings; and (c) failures which resulted from the specimens pulling out of the end fittings.

\section{DISCUSSION}

The test results presented herein will be used, together with the results obtained by the other participating testing organizations, to assess and compare the different test methods. Presumably, statistical analyses will be employed. In doing so it must be borne in mind that the numerical results by themselves can be misleading; the meaning of each numerical value should be considered in the context of the failure mode with which it is associated. 
The failure modes obtained in the tests were classified into three categories, each of which has a different significance. When a tensile failure initiates in the free length of a specimen, i.e., at a location removed from the end fittings, the measured strength is by definition the strength of the rod tested. If the failure initiates in or adjacent to an end fitting, the measured strength value may or may not be close to the strength of the rod. Without further data it is impossible to tell whether or not the strength reductions imposed by the fitting were severe. If the rod simply pulls out of an end fitting, without exhibiting significant damage elsewhere, it is probable that the strength of the rod was not approached. Several examples using the data in Table 1 will serve to illustrate these remarks.

Example 1. All of the 1/2-in (13-mm) black-coded rods failed in or adjacent to an end fitting. As such, it is impossible to determine whether or not the strengths of the rods were approached. In the tests of the 1/2-in (13-mm) orange-coded rods, on the other hand, three specimens failed in or near a fitting while two failed in their free lengths. Yet, all of the measured strength values were close to one another. In this case, therefore, it is apparent that the strengths of the rods were, indeed, approached even in those tests which culminated in an end-fitting failure.

Example 2. Five 1/8-in (3-mm) black-coded rods were tested with the shear-type fittings and one with the Reliable end fittings. The measured strength values for the five specimens tested with pipe fittings were close to one another, despite the fact that three of these failed in their free lengths while two failed in or near one of the fittings. It is clear, therefore, that the strength of the rod was closely approached even in those tests in which end-fitting failures were obtained. The sixth specimen failed in one of its Reliable fittings at a somewhat lower load than the others. By itself, there would be no way of knowing whether or not the strength of the material was approached in this test. However, by comparison with the results of the other five tests it becomes apparent that the strength of the rod was not approached in the sixth test and that the pipe fitting was more effective than the Reliable fitting for this material in this application.

Example 3. Five tests of 1/8-in (3-mm) blue-coded rods were performed with pipe fittings and one with Reliable fittings. The five tests with pipe fittings all culminated in pullout failures. The sixth specimen failed in one of its Reliable fittings at a substantially higher load. It is clear that the strength of the rod was not approached with the pipe fittings and that the Reliable fitting was more suitable for this material in this application. However, there is no way of knowing if the strength of the rod was approached even with the Reliable fittings. 
Example 4. Five tests of 1/8-in (3-mm) green-coded rods were performed with pipe fittings and four with Reliable fittings. All of the tests with pipe fittings culminated in pullout failures. Two of the specimens tested with Reliable fittings failed in their free lengths and two in or near one of the fittings. The measured strength values in the latter four tests were generally greater than those obtained with the pipe fittings and were all reasonably close to one another. In this case it is not only clear that the Reliable fitting was preferable to the pipe for this material, but also that the strength of the rod was approached even when the specimens failed in or near one of their Reliable fittings. 



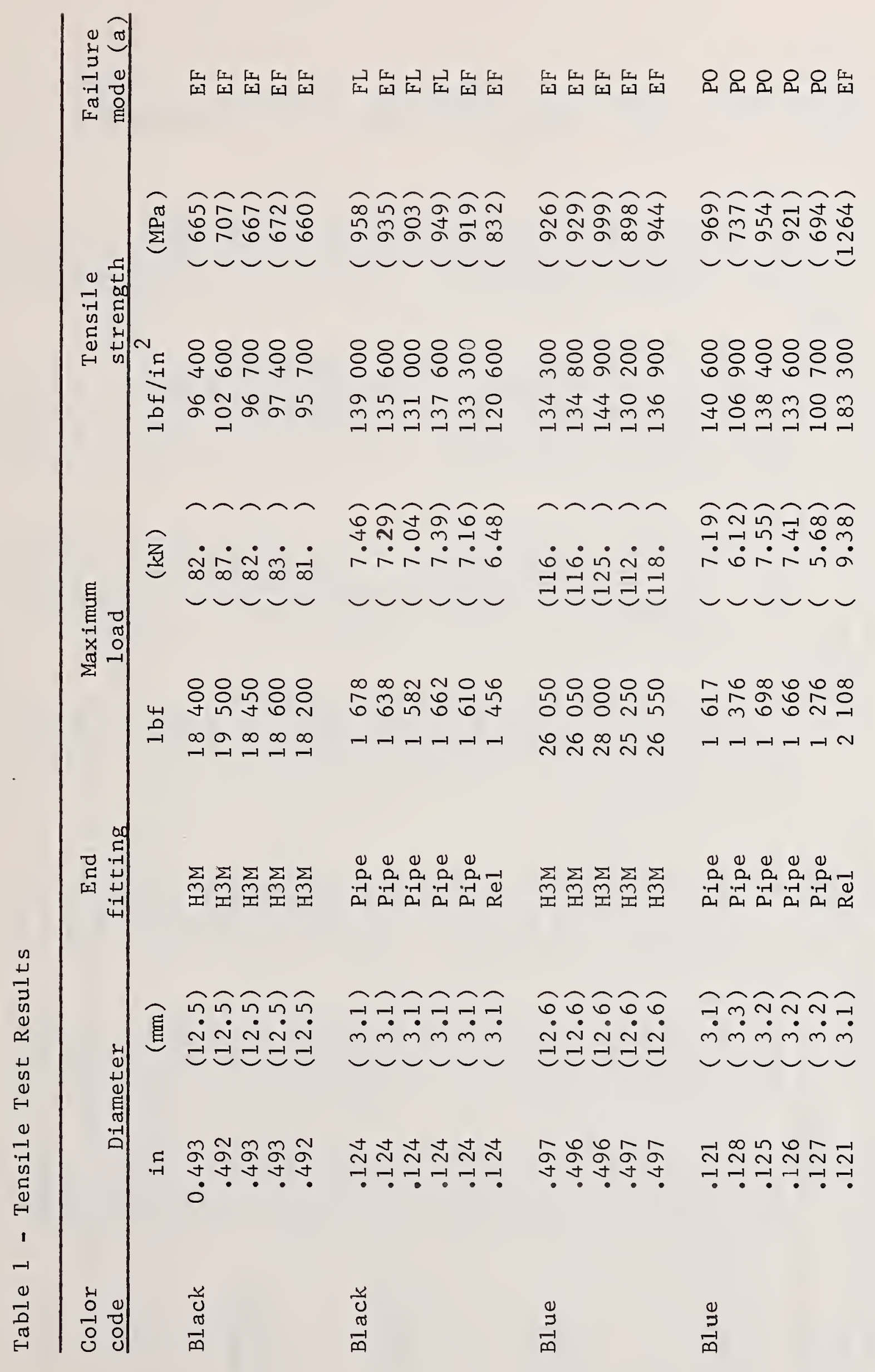




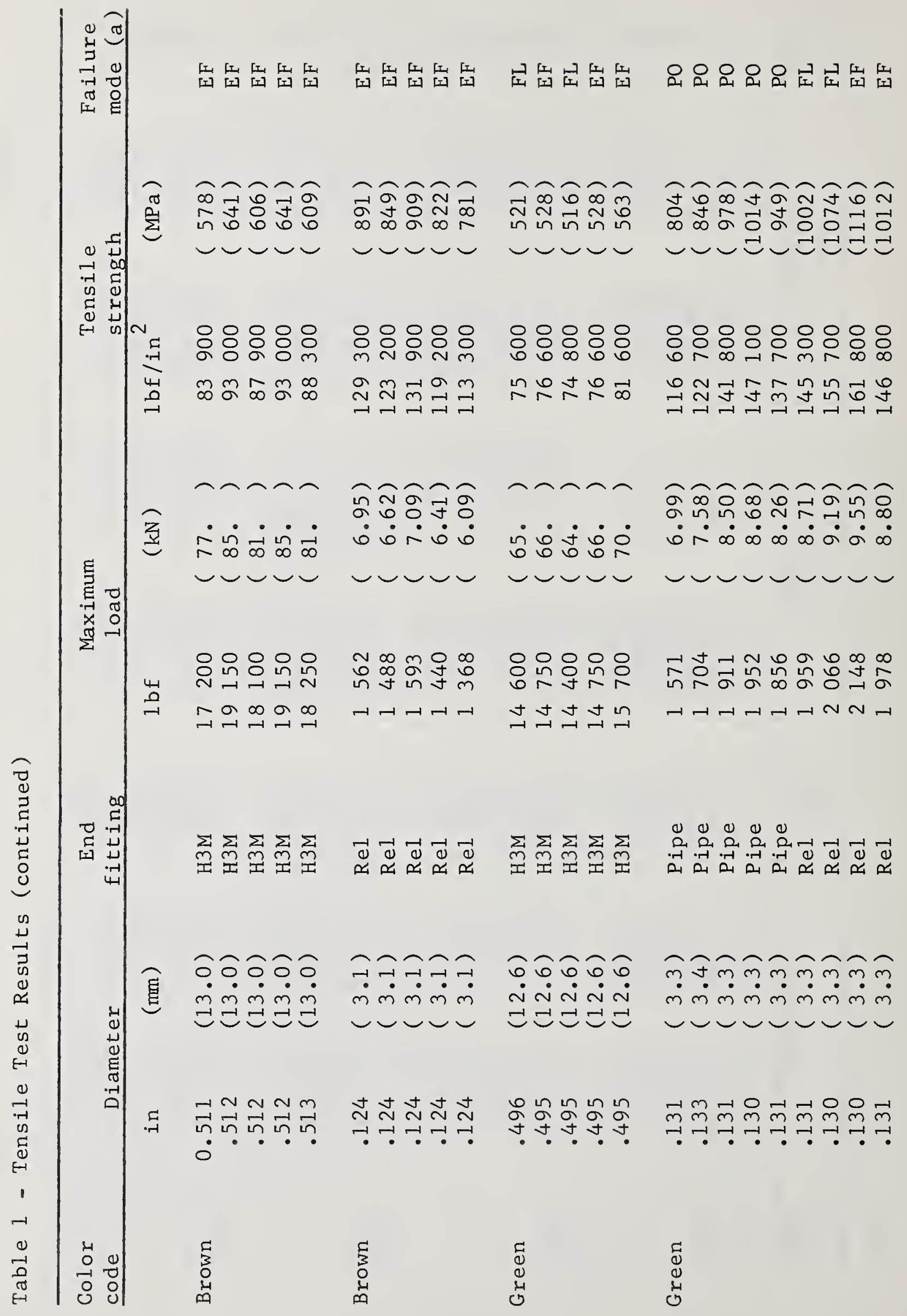




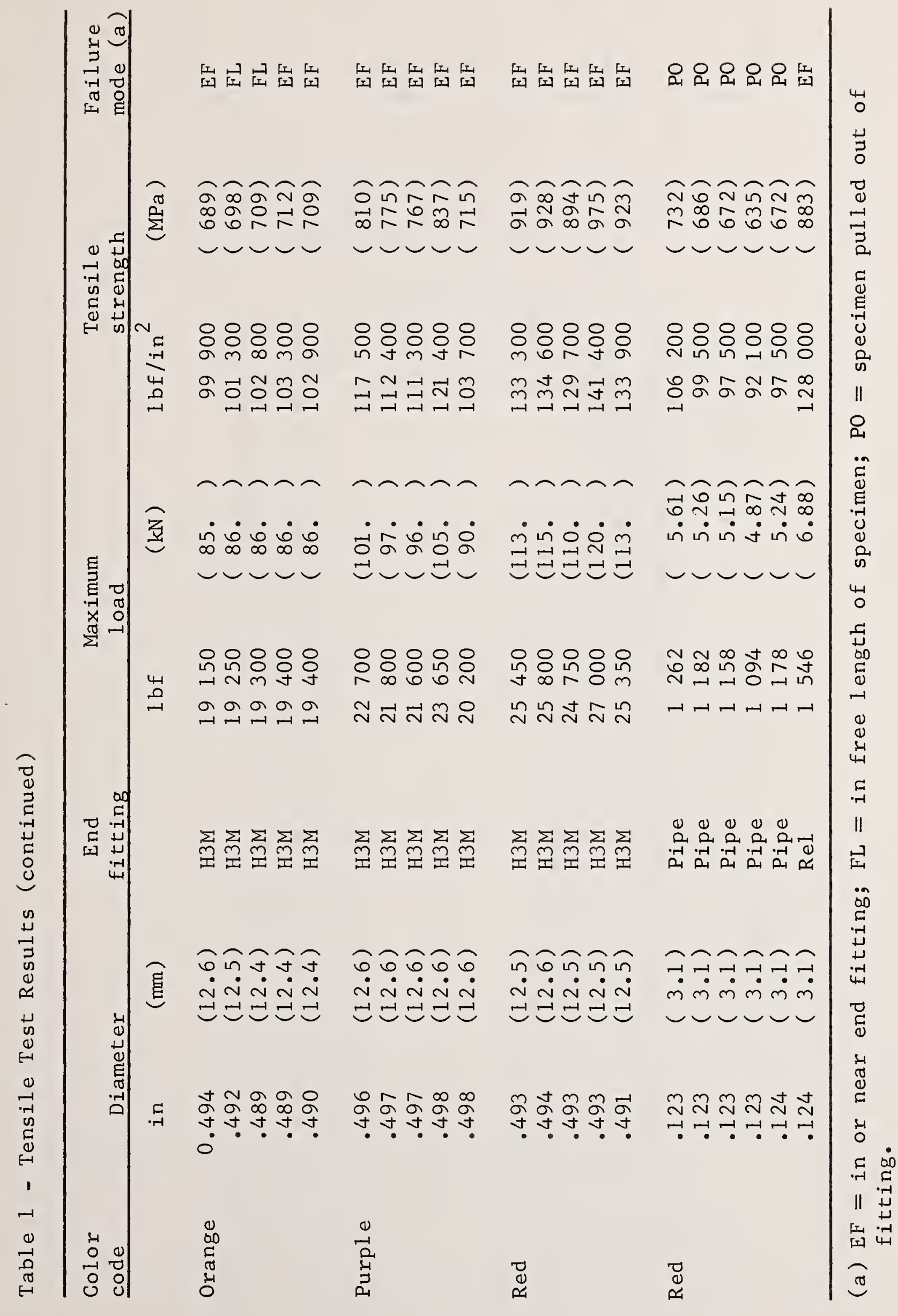





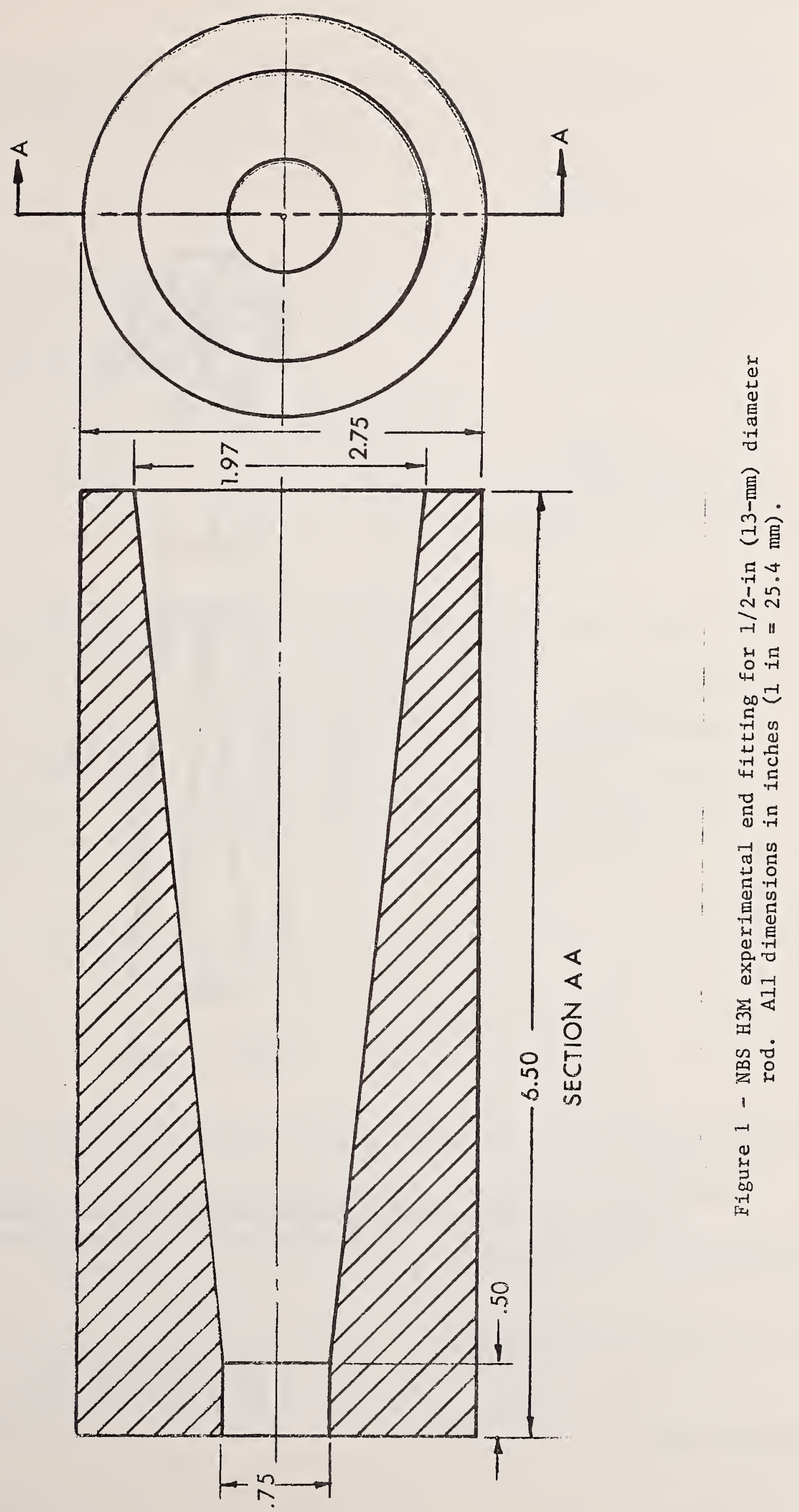



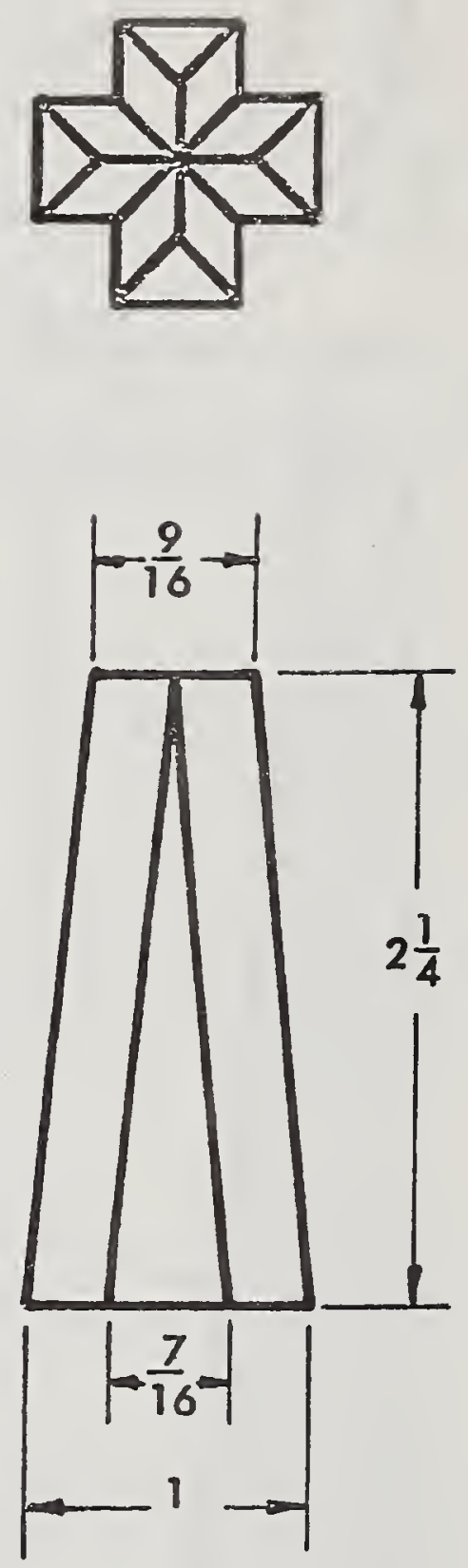

Figure 2 - Cruciform wedge for 1/2-in (13-mm) diameter rod. All dimensions in inches ( 1 in $=25.4 \mathrm{~mm}$ ) 


\begin{tabular}{|c|c|c|}
\hline \begin{tabular}{c|c} 
U.S. DEPT. OF COMM. & 1. PUIBI.ICATION OR RIPORT NO. \\
BIBLIOGRAPHIC DATA & NBSIR $76-1079$ \\
SHEET & NBSIR
\end{tabular} & $\begin{array}{l}\text { 2. Gov't Accession } \\
\text { No. }\end{array}$ & 3. Recipient's Accession No. \\
\hline \multicolumn{2}{|l|}{ 4. TITI.E AND SUBTITI.E } & $\begin{array}{l}\text { 5. Publication Date } \\
\text { April } 1976\end{array}$ \\
\hline \multicolumn{2}{|l|}{ TENSILE TESTS OF PULTRUDED ROUND RODS } & 6. Performing Organization Code \\
\hline \multicolumn{2}{|l|}{$\begin{array}{l}\text { 7. AUTHOR(S) } \\
\text { Nixon Hal sey and Leonard Mordfin }\end{array}$} & 8. Performing Organ. Report No. \\
\hline \multicolumn{2}{|l|}{ 9. PERFORMING ORGANIZATION NAME ANI) ADDRESS } & $\begin{array}{l}\text { 10. Project/Task/Work Unit No. } \\
2130141\end{array}$ \\
\hline $\begin{array}{l}\text { NATIONAL BUREAU OF STANDARDS } \\
\text { DEPARTMENT OF COMMERCE } \\
\text { WASHINGTON, D.C. } 20234\end{array}$ & & 11. Contract/Grant No. \\
\hline \multirow{2}{*}{\multicolumn{2}{|c|}{ 12. Sponsuing urganization Name and Complete Address (Srreex, Ciky, State, EIP) }} & $\begin{array}{l}\text { 13. Type of Report \& Period } \\
\text { Covered } \\
\text { Fina1, } 12 / 75-3 / 76\end{array}$ \\
\hline & & 14. Sponsoring Agency Code \\
\hline
\end{tabular}

15. SUPPLEMENTARY NOTES

16. ABSTRACT (A 200-word or less factual summary of most significant information. If document includes a significant bibliography or literature survey, mention it here.)

The Engineering Mechanics Section of the National Bureau of Standards (NBS) conducted sixty-seven tensile tests on pultruded round rods as part of an ASTM interlaboratory testing program which was established to assess and to compare various test methods which are currently used by different testing organizations. The test methods used by NBS are described and the test results are given.

17. KEY WORDS (six to twelve entries; alphabetical order; capitalize only the first letter of the first key word unless a proper name; separated by semicolons)

Interlaboratory tests; plastics, glass fiber-reinforced; pultrusions; reinforced plastics; round-robin tests; tensile strength; tensile tests; test methods, tensile; standards, voluntary.
18. AVAILABILITY
[.] Unlimited

X For Official Distribution. Do Not Release to NTIS

Order From Sup. of Doc., U.S. Government Printing Office Washington, D.C. 20402, SD Cat. No. C13

Order From National Technical Information Service (NTIS) Springfield, Virginia 22151

\begin{tabular}{|l|l|}
\hline $\begin{array}{l}\text { 19. SECURITY CLASS } \\
\text { (THIS REPURT) }\end{array}$ & 21. NO. OF PAGES \\
UNCL ASSIFIED & 22. Price \\
\hline $\begin{array}{l}\text { 20. SECURITY CLASS } \\
\text { UNIS PAGE) }\end{array}$ & \\
\hline
\end{tabular}



NBSIR $76-1080$ to be published as SP. ; NOT AS AN NOBLER 
